\title{
PENGARUH VARIABEL MAKRO EKONOMI TERHADAP HARGA SAHAM DENGAN PROFITABILITAS SEBAGAI VARIABEL INTERVENING PADA PERUSAHAAN MANUFAKTUR DI BURSA EFEK INDONESIA
}

\author{
Kornel Munthe ${ }^{1}$, Caisar J Harefa ${ }^{2}$ \\ ${ }^{1,2}$ Fakultas Ekonomi Universitas Katolik Santo Thomas Medan \\ Email: kornel_munthe@yahoo.com
}

\begin{abstract}
:
The purpose of this study is to influence the effect of exchange rates, interest rates, inflation and Gross Domestic Product on stock prices with profitability as an intervinig variable in manufacturing companies on the Indonesia Stock Exchange. This type of research is explanatory. The population in this study were all manufacturing companies listed on the Indonesia Stock Exchange as many as 159 companies with a total sample of 61 companies. The type of data used is secondary data collected by documentation techniques. The results showed that the exchange rate had a negative and significant effect on profitability, SBI interest rates, inflation and Gross Domestic Product partially had a positive and significant effect on profitability, exchange rate variables, SBI interest rates, inflation and Gross Domestic Product simultaneously had a significant effect on profitability, exchange rates and SBI interest rates partially have a negative and significant effect on stock prices, inflation, and Gross Domestic Product and Return on Assets have a positive and significant effect on stock prices, and exchange rate variables, SBI interest rates, inflation, and Domestic Product Gross and profitability simultaneously have an effect and are significant on stock prices.
\end{abstract}

\section{PENDAHULUAN}

Pasar modal di Indonesia menjalankan dua fungsi sekaligus, yaitu fungsi ekonomi dan fungsi keuangan. Dalam menjalankan fungsi ekonomi dengan cara mengalokasikan dana secara efisien dari pihak yang memiliki kelebihan dana sebagai pemilik modal kepada perusahaan yang terdaftar di pasar modal. Sedangkan fungsi keuangan dari pasar modal ditunjukkan oleh kemungkinan dan kesempatan mendapatkan imbalan bagi pemilik dana atau investor sesuai dengan karakter investasi yang dipilih. Bagi kalangan masyarakat yang memiliki kelebihan dana dan berminat untuk melakukan investasi, hadirnya lembaga pasar modal di Indonesia menambah deretan alternatif untuk menanamkan dananya. Jenis surat berharga yang diperjualbelikan dipasar tersebut, salah satunya adalah saham. Saham perusahaan manufaktur sebagai komoditi investasi tergolong beresiko karena sifatnya yang peka terhadap perubahan-perubahan yang terjadi baik oleh pengaruh yang bersumber dari luar ataupun dari dalam negeri. Perubahan tersebut antara lain dibidang politik, ekonomi, moneter, undang-undang atau peraturan maupun perubahan yang terjadi dalam industri dan perusahaan yang mengeluarkan saham itu sendiri.

Penilaian saham dapat dilakukan melalui fundamental analysis dan technical analysis. Analisis fundamental terbagi menjadi tiga bagian, yaitu: (a) Analisis ekononomi dan pasar modal; (b) Analisis industry, dan (c) Analisis perusahaan. Tiga bagian tersebut merupakan langkah dari top-down analisis fundamental. Analisis teknikal bisa didefenisikan sebagai penggunaan data pasar yang spesifik untuk menganalisis agregat harga saham dan harga saham individual. Seorang analisis teknikal memiliki filosofi bahwa analisis dapat mengetahui pola-pola pergerakan harga saham di masa lalu. Melalui observasi, pola-pola tersebut digunakan untuk mngetahui pergerakan harga saham saat ini atau dimasa yang akan datang. Umumnya analisis teknikal banyak digunakan oleh investor yang ingin mengambil keuntungan jangka pendek.

Faktor utama yang menyebabkan harga pasar saham berubah adalah adanya persepsi yang berbeda dari masing-masing investor sesuai informasi yang dimiliki. Menurut Bramantio et al, (2013) bahwa faktor fundamental makroekonomi yaitu, inflasi, tingkat suku bunga, kurs dan pertumbuhan ekonomi merupakan faktor-faktor yang sangat diperhatikan oleh pelaku pasar bursa. Perubahanperubahan yang terjadi pada faktor ini dapat mengakibatkan perubahan-perubahan di pasar modal, yaitu meningkat atau menurunnya harga saham. Faktor yang dapat mempengaruhi harga saham yang

Pengaruh Variabel Makro Ekonomi Terhadap Harga Saham dengan Profitabilitas Sebagai 


\section{Volume 20 Nomor 2, September 2020}

biasanya dipertimbangkan oleh investor adalah kinerja fundamental perusahaan untuk menghasilkan laba, pergerakan suku bunga bank, tingkat inflasi, kurs nilai tukar mata uang, serta kondisi sosial politik suatu negara.

Perusahaan manufaktur adalah perusahaan industri pengolahan bahan baku menjadi barang setengah jadi atau barang jadi. Perusahaan manufaktur identik dengan pabrik yang mengaplikasikan mesin-mesin peralatan, teknik rekayasa, dan tenaga kerja. Istilah ini bisa digunakan untuk aktivitas manusia dari kerajinan tangan sampai ke produksi sampai dengan teknologi tinggi. Namun demikian, istilah ini lebih sering digunakan untuk dunia industri, dimana bahan baku diubah menjadi barang jadi dalam skala besar. Perusahaan manufaktur dinilai mempunyai prospek cerah seiring dengan perkembangan ekonomi. Perusahaan ini dapat bertahan di tengah kondisi perekonomian Indonesia karena pendiriannya yang semakin banyak diharapkan dapat memberikan prospek yang menguntungkan untuk memenuhi kebutuhan masyarakat.

Perusahaan manufaktur memiliki karakteristik padat modal karena merupakan jenis industri yang memerlukan modal finansial yang besar dan di dukung oleh teknologi yang tinggi. Seiring dengan meningkatnya aktivitas perdagangan, kebutuhan untuk memberikan informasi yang lebih lengkap kepada masyarakat mengenai perkembangan bursa, juga semakin meningkat. Salah satu informasi yang diperlukan tersebut adalah indeks harga saham sebagi cerminan dari pergerakan harga saham. Indeks saham tersebut terus menerus disebarluaskan melalui media cetak maupun elektronik sebagai salah satu pedoman bagi investor untuk berinvestasi di pasar modal.

Adapun rata-rata harga saham periode tahun 2014-2017 mengalami fluktuasi dan cenderung meningkat yakni pada tahun 2014 rata-rata harga saham perushaan sebesar Rp 4135,82 dan pada tahun 2017 menjadi Rp 4881,28. Terjadinya fluktuasi harga saham tersebut dipengaruhi oleh banyak faktor diantaranya: nilai tukar atau kurs. Penguatan kurs (apresiasi) rupiah terhadap mata uang asing merupakan tanda yang positif bagi investor. Ketika kurs rupiah terhadap mata uang asing mengalami penguatan maka akan banyak investor berinvestasi pada saham, hal tersebut dikarenakan penguatan mengindikasikan bahwa perekonomian dalam keadaan bagus dan sebaliknya. Berdasarkan fakta yang terjadi nilai tukar Dollar Amerika terhadap Rupiah mengalami fluktuasi dan cenderung mengalami depresisi yakni pada tahun 2014 untuk mendapatkan US\$1 kita cukup mengeluarka rupiah sebesar Rp 12.502 saja, namun pada tahun 2017 menjadi Rp 13.616.

Tingkat suku bunga merupakan faktor makroekonomi lainya yang mempengaruhi harga saham. Ketika suku bunga mengalami peningkatan maka harga saham akan mengalami penurunan begitu juga sebaliknya. Tingginya tingkat suku bungaakan membuat investor akan beralih pada tabungan atau deposito yang mengakibatkan saham tidak diminati sehingga saham pun akan turun. Berdasarkan fakta yang terjadi rata-rata tingkat suku bunga mengalami fluktuasi dan cenderung mengalami penurunan sejak tahun 2014-2017 yakni pada tahun 2014 rata-rata suku bunga sebesar 7,53 persen dan tahun 2017 menjadi 4.56 persen. Bramantio et. all (2013) mengemukakan ada dua pendapat mengenai hubungan antara tingkat inflasi dengan harga saham. Pendapat pertama menyatakan bahwa ada korelasi positif antara inflasi dengan harga saham. Pendapat ini didasarkan pada asumsi bahwa inflasi yang terjadi adalah demand and inflation, yaitu inflasi yang terjadi karena adanya kelebihan permintaan atas penawaran barang yang tersedia. Inflasi seperi ini, perusahaan membebankan peningkatan biaya kepada konsumen dengan proporsi yang lebih besar sehingga keuntungan perusahaan meningkat. Dengan demikian akan meningkatkan kemampuan perusahaan untuk membayar dividen dan akan memberikan penilaian positif pada harga saham.

Pendapat yang kedua menyatakan bahwa ada korelasi negatif antara inflasi dengan harga saham. Pendapat ini didasarkan pada asumsi bahwa inflasi yang terjadi adalah cost push inflation, yaitu inflasi yang terjadi karena kenaikan biaya produksi. Adanya kenaikan harga bahan baku dan tenaga kerja, sementara perekonomian dalam keadaan inflasi, maka produsen tidak mempunyai keberanian untuk menaikkan harga produknya. Hal ini akan mengakibatkan keuntungan perusahaan untuk membayar dividen menurun yang akan berdampak pada penilaian harga saham yang negatif. Berdasarkan fakta bahwa inflasi yang terjadi cenderung mengalami penurunan (deflasi) sejak tahun 2014-2017 yakni pada tahun 2014 tingkat inflasi sebesar 6,42 persen dan pada tahun 2017 menjadi 3,81 persen. Faktor makro lainnya yang perlu diperhatikan lagi adalah Produk Domestik Bruto. PDB adalah jumlah produksi barang dan jasa yang dihasilkan oleh unit-unit produksi pada suatu daerah di saat-saat 


\section{Volume 20 Nomor 2, September 2020}

tertentu. PDB yang tumbuh cepat menunjukkan pertumbuhan ekonomi yang berdampak pada meningkatnya daya beli masyarakat. Ini menjadi peluang meningkatkan penjualannya yang menghasilkan keuntungan dan naiknya harga saham sehingga nilai perusahaan akan terdorong naik. Oleh karena itu bagi investor pertumbuhan ekonomi digunakan sebagai pertimbangan dalam melakukan investasi. Fakta yang ada menunjukkan bahwa laju pertumbuhan PDB mengalami fluktuasi dan cenderung mengalami penurunana periode tahun 2014-2017 yakni pada tahun 2014 tingkat pertumbuhan PDB sebesar 5,06 persen menjadi 4.55 persen pada tahun 2017. Hal ini menunjukkan bahwa presentase pertumbuhan PDB mengalami ketidakpastian. Inflasi, suku bunga, nilai tukar (kurs) yang berfluktuasi dan PDB yang mengalami ketidakpastian memberikan dampak bagi perekonomian di Indonesia termasuk pada perusahaan manufaktur.

Tujuan utama perusahaan adalah meningkatkan nilai perusahaan guna memberikan kemakmuran yang kekal kepada pemegang saham. Nilai perusahaan yang tinggi akan mempengaruhi persepsi para investor yang dapat memengaruhi mereka untuk lebih percaya diri dan percaya pada prospek perusahaan di masa depan. Nilai perusahaan sering dikaitkan dengan persepsi investor terhadap keberhasilan perusahaan. Semakin tinggi harga saham, semakin tinggi pula nilai perusahaan yang menunjukkan prospek perusahaan di masa yang akan datang. Dengan demikian, tujuan perusahaan untuk memaksimalkan kemakmuran pemegang saham dapat diwujudkan dengan memaksimalkan nilai perusahaan.

Maksimisasi nilai perusahaan berarti maksimisasi kekayaan atau kemakmuran dari pemegang saham dan pihak lain yang terkait. Nilai perusahaan dapat ditingkatkan apabila tingkat profitabilitas perusahaan mengalami kenaikan yang terus berkelanjutan. Tingkat profitabilitas dijadikan sebagai acuan bagi pemilik modal untuk menentukan pilihan akan berinvestasi di perusahaan tersebut atau tidak. Apabila tingkat profitabilitas di suatu perusahaan terus mengalami kenaikan, maka investor akan cenderung memilih berinvestasi di perusahaan tersebut. Perusahaan yang dapat meningkatkan profitnya secara stabil, maka hal tersebut dipandang sebagai sinyal positif oleh investor terkait kinerja perusahaan, sehingga hal ini akan meningkatkan nilai perusahaan. Artinya, semakin meningkatnya profitabilitas di suatu perusahaan, semakin meningkat pula daya minat beli bagi investor untuk memiliki sebagian saham di perusahaan tersebut. Dengan meningkatnya ketertarikan inyestor ingin memiliki sebagian saham perusahaan tersebut akan membuat investor rela membayar mahal untuk saham pembayaran tinggi. Dalam kondisi seperti ini maka nilai perusahaan akan mengalami kenaikan.

Berdasarkan uraian di atas, maka penulis tertarik untuk melakukan penelitian dengan judul "Pengaruh Variabel Makroekonomi Terhadap Harga Saham Dengan Profitabilitas Sebagai Variabel Intervening Pada Perusahaan Manufaktur Yang Terdaftar Di Bursa Efek Indonesia".

\section{TINJAUAN PUSTAKA}

\section{Analisis Fundamental dan Teknikal}

Analisis fundamental adalah studi tentang ekonomi, industri dan kondisi perusahaan untuk memperhitungkan nilai dari saham perusahaan. Analisis fundamental menitik beratkan pada data-data kunci dalam laporan keuangan perusahaan untuk memperhitungkan apakah harga saham sudah di apresiasikan secara akurat. Analisis fundamental adalah cara mengetahui saham yang berkinerja baik atau berkinerja buruk, sehingga dapat memutuskan sekuritas yang "layak di beli" atau "layak dijual" Samsul (2015). Perubahan harga saham setiap waktu tidak dapat diprediksi apabila pelaku investasi, khususnya perusahaan, tidak melakukan suatu analisis. Analisis yang paling sesuai dengan harga saham adalah analisis fundamental, karena dengan analisis fundamental perusahaan, akan memperhitungkan risiko dan harga saham yang terjadi maupun yang sedang terjadi. Analisis fundamental diperlukan untuk memperhitungkan risiko dan keuntungan yang bisa diterima berupa dividen atau capital gain.

\section{Harga Saham}

Harga saham adalah harga pasar yang tercatat setiap hari pada waktu penutupan (closing price) dari suatu saham. Harga saham yang terjadi di pasar modal selalu berfluktuasi dari waktu ke waktu. Fluktuasi dari harga suatu saham tersebut akan ditentukan antara kekuatan penawaran dan permintaan. Jika jumlah penawaran lebih besar daripada harga permintaan, pada umumnya kurs harga saham akan 


\section{Volume 20 Nomor 2, September 2020}

turun. Sebaliknya jika jumlah permintaan lebih besar dari jumlah penawaran terhadap suatu efek, maka harga saham cenderung akan naik. Harga saham merefleksikan seberapa besar kekuatan permintaan dibandingkan kekuatan penawaran terhadap suatu saham, sementara banyaknya investor yang ingin menjual tetap maka harga saham akan cenderung naik. Sebaliknya, jika lebih banyak investor yang ingin menjual sahamnya daripada investor yang ingin membeli saham cenderung akan mneurunkan harga saham.

\section{Faktor-Faktor yang Mempengaruhi Kinerja Pasar Modal}

Pasar modal menjadi media uang dapat digunakan untuk memperoleh dana, baik dari dalam maupun luar negeri di mana terjadi alokasi dana dari pihak yang kelebihan dana ke pihak yang memerlukan dana. Semakin baiknya kinerja pasar modal Indonesia menciptakan peluang yang tinggi bagi para investor dalam negeri maupun luar negeri untuk berinvestasi khususnya di investasi saham. Akan tetapi, investor memandang investasi di pasar modal khususnya saham memiliki resiko yang tinggi "high risk high return". Terlebih pasar modal Indonesia merupakan pasar yang masih berkembang yang menjadikan pemnyampaian informasi kurang efesien.

Informasi yang dimakasud terkait dengan informasi harga saham yang banyak digunakan para investor sebagai ukuran kinerja perusahaan. Harga saham merupakan harga suatu saham yang terjadi di pasar bursa pada saat tertentu yang ditentukan oleh pelaku pasar dan ditentukan oleh permintaan dan penawaran saham yang bersangkutan di pasar modal (Jogiyanto, 2010). Harga saham yang cukup tinggi akan memberikan keuntungan, yaitu berupa capital gain dan citra yang lebih baik bagi perusahaan sehingga memudahkan manajemen untuk mendapatkan dana dari luar perusahaan. Terdapat beberapa faktor yang mempengaruhi harga saham perusahaan baik yang berasal dari faktor fundamental maupun makroekonomi perusahaan. Informasi yang didapat dari kondisi intern perusahaan yang berupa informasi keuangan dan informasi non keuangan. Rasio profitabilitas dapat memberikan informasi mengenai kinerja keuangan perusahaan. Rasio profitabilitas merupakan salah satu rasio yang bertujuan untuk mengukur efesiensi-aktivitas perusahaan dan kemampuan perusahaan untuk memperoleh keuntungan. Harmono (2009) menyatakan bahwa analisis rasio profitabilitas menggambarkan kinerja fundamental perusahaan ditinjau dari tingkat efesiensi dan efektivitas operasi perusahaan dalam memperoleh laba. Rasio profitabilas merupakan daya tarik utama dari perusahaan bagi para pemegang saham perusahaan. Beberapa faktor makroekonomi yang diduga dapat memepengaruhi pasar modal dan menjadi variabel independen yang digunakan dalam penelitian ini diantaranya: (a) nilai tukar mata uang, (b) suku bunga, (c) inflasi, dan (d) produk domestik bruto

\section{Pengaruh Nilai Tukar Terhadap Harga Saham Dengan Profitabilitas Sebagai Variabel Intervinig.}

Menurut Mankiew (2007) bahwa kurs mata uang asing menunjukkan harga atau nilai mata uang suatu negara dinyatakan dalam mata uang negara lain. Kurs mata uang asing dapat juga didefenisikan sebagai jumlah uang domestik yang dibutuhkan, yaitu banyaknya rupiah yang dibutuhkan untuk memperoleh satu unit mata uang asing. Nilai tukar satu mata uang tersebut mempengaruhi perekonomian apabila nilai mata uang tesebut terapresiasi atau terdepresiasi. Ketika mata uang suatu negara melemah terhadap mata uang negara lain, biaya produksi yang mengandalkan bahan baku impor akan naik. Kondisi ini secara otomatis akan menurunkan laba perusahaan atau margin laba. Hal tersebut senada dengan hasil penelitian Hidayati (2014) dan Prastowo, Malavia dan Wahono (2014). Namun, A'yun (2017) dalam penelitianya menyatakan bahwa kurs (nilai tukar) secara langsung berpengaruh negatif dan signifikan terhadap profitabilitas.

Menurunya kurs Dollar terhadap Rupiah berpengaruh positif terhadap ekonomi dan pasar modal, sebaliknya meningkatnya kurs Dollar terhadap Rupiah berpengaruh negatif terhadap ekonomi dan pasar modal Farid Harianto (2000) dalam Thobbary (2009). Melemahnya rupiah akan menyebabkan pasar modal dalam negeri kurang menarik karena adanya resiko nilai tukar yang menyebabkan penurunan nilai investasi dan mempunyai hubungan negatif terhadap return saham. Sebaliknya, hubungan antara nilai tukar Dollar terhadap Rupiah bias saja berpengaruh positiif bila investor berasal dari luar negeri dan menggunakan mata uang asing sehingga semakin terdepresiasinya mata uang Rupiah akan menyebabkan investor luar cenderung melepeas mata uang asingmnya untuk 


\section{Volume 20 Nomor 2, September 2020}

membeli saham yang harganya turun karena pengaruh kurs mata uang. Hasil Penelitian dari Mardiyati dan Rosalina (2013) menunjukkan bahwa hasil nilai tukar memberikan pengaruh negatif terhadap indeks harga saham pada perusahaan properti yang terdaftar di BEI dan juga hasil penelitian dari Kewal (2012).

\section{Pengaruh Suku Bunga BI Rate Terhadap Harga Saham Dengan Profitabilitas Sebagai Variabel Intervinig.}

Menurut Saputro (2018) BI Rate adalah suku bunga kebijakan yang mencerminkan sikap atau stance kebijakan moneter yang ditetapkan oleh Bank Indonesia dan diumumkan kepada publik. BI Rate diumumkan oleh gubernur Bank Indonesia setiap rapat dewan gubernur bulanan dan diimplementasikan pada operasi moneter yang dilakukan Bank Indonesia melalui pengelolaan liquiditas (Liquidty Management) di pasar uang untuk mencapai sasaran operasional kebijakan moneter. Hampir setiap perusahaan membutuhkan pembiayaan baik itu dari pemegang saham ataupun pihak eksternal seperti Bank. Bisnis membutuhkan pembiayaan untuk mendanai berbagai aktivitas bisnisnya agar terus bisa menghasilkan kesejahteraan bagi pemegang saham. Ketika BI Rate naik, maka akan diikuti dengan naiknya suku bunga lain dalam konteks ini suku bunga kredit. Naiknya suku bunga kredit akan meningkatkan biaya sehingga kondisi ini akan menurunkan kemampuan perusahaan untuk mengembangkan bisnisnya.

Ketika suku bunga yang ditetapkan oleh Bank Indonesia meningkat, maka pada dasarnya akan menaikkan suku bunga kredit yang dikeluarkan oleh Bank. Dengan meningkatnya suku bunga maka akan mempengaruhi permintaan akan kredit property (subprime mortgage). Dengan naiknya suku bunga kredit akan mempengaruhi permintaanakan property yang nantinya akan mempengaruhi kineja perusahaan property yang terdaftar di pasar saham. Mardiyati dan Rosalina (2013) menunjukkan hasil bahwa suku bunga memiliki pengaruh yang positif namun tidak signifikan terhadap indeks harga saham properti. Namun Budiantara (2012) menyatakan bahwa variabel tingkat suku bunga berpengaruh secara negatif dan signifikan terhadap harga saham.

\section{Pengaruh Inflasi Terhadap Harga Saham Dengan Profitabilitas Sebagai Variabel Intervinig.}

Menurut Mankiew (2007) bahwa inflasi adalah kenaikan harga-harga secara umum berlaku dalam suatu perekonomian dari satu periode ke periode lainnya, sedangkan tingkat infasi adalah presentasi kenaikan harga-harga pada satu tahun tertentu dibanding dengan tahun sebelumnya. Kenaikan harga barang yang disebabkan inflasi tentunya akan menambah pengeluaran produksi perusahaan manufaktur. Apabila pengeluaran produksi bertambah, maka akan mengurangi laba perusahaan tersebut. Hal tersebut senada dengan penelitian Sahara (2013). Sedangkan, Kalengkongan (2011) menyebutkan bahwa inflasi berpengaruh negatif terhadap profitabilitas.

Inflasi adalah proses naiknya harga secara umum ddan keseluruhan. Dengan kenaikan beberapa harga barang saja belum dapat dikatakan inflasi. Inflasi sebagai akibat dari jumlah uang yang beredar di masyarakat terlalu banyak. Naiknya inflasi akan mengakibatkan harga barang menjadi mahal dan tingkat suku bunga juga akan naik. Jika terjadi kenaikan pada barang-barang dan kemudian suku bunga naik, maka masyarakat tidak akan membelanjakan uangnya dan akan cenderung menggunakan uangnya dalam bentuk tabungan. Hasil penelitian sebelumnya yang dilakukan oleh Thobarry (2009) mendapatkan hasil bahwa inflasi berpengaruh negatif dan signifikan terhadap indeks harga saham sektor property. Berbeda dengan hasil penelitian yang dilakukan oleh Asih dan Akbar (2016) yang menyatakan bahwa inflasi berpengaruh positif terhadap indeks harga saham gabungan.

\section{Pengaruh PDB Terhadap Harga Saham Dengan Profitabilitas Sebagai Variabel Intervinig.}

Menurut Krissandy (2013) PDB adalah nilai barang dan jasa yang dihasilkan di suatu negara dalam satu tahun tertentu. PDB dapat mengukur total pendapatan maupun total pengeluaran perekonomian untuk barang dan jasa. Sehingga PDB per kapita dapat memberitahu kita pendapatan dan pengeluaran dari rata-rata seseorang dalam perekonomian, karena kebanyakan orang lebih memilih pendapatan dan pengeluaran yang lebih tinggi. PDB dibagi dalam empat komponen pengeluaran, yaitu: (i) Konsumsi (ii) Investasi (iii) Pembelanjaan Pemerintah dan (iv) Eksport Netto. PDB yang meningkat mempunyai pengaruh yang positif terhadap daya beli konsumen sehingga dapat meningkatkan 


\section{Volume 20 Nomor 2, September 2020}

permintaan terhadap produk perusahaan yang pada akhirnya dapat meningkatkan profitabilitas perusahaan. Riyanto dan Asakdiyah (2016) dan Sodiq (2015) yang menyebutkan bahwa PDB berpengaruh positif terhadap profitabilitas. Produk domestik bruto dinilai menurut harga pasar dan dapat didasarkan kepada harga yang berlaku dan harga tetap. Formula PDB yaitu PNB - PF dari LN. PNB merupakan produk nasional suatu negara, sementara PF dari LN merupakan pendapatan factorfaktor produksi yang diterima dari luar negeri dikurangi dengan factor-faktor produksi yang dibayarkan keluar negeri. Dalam menghitung pendapatan nasional diperlukan adanya produk domestik bruto.

Meningkatnya PDB merupakan sinyal yang baik (positif) untuk investasi dan sebaliknya, menurunnya PDB memberikan pengaruh negatif terhadap daya beli konsumen sehingga dapat menurunkan permintaan terhadap produk perusahaan. Adanya peningkatan permintaan terhadap produk perusahaan akan meningkatkan profit perusahaan dan pada akhirnya dapat meningkatkan harga saham perusahaan.

Hasil penelitian Hismendi et al (2013) dan Prasetyanto (2016) menemukan bahwa PDB berpengaruh positif dan signifikan terhadap harga saham. Peningkatan PDB mencerminkan peningkatan daya beli konsumen di suatu negara. Adanya peningkatan daya beli konsumen menyebabkan peningkatan permintaan masyarakat terhadap barang dan jasa perusahaan yang nantinya akan meningkatkan profit perusahaan. Peningkatan profit perusahaan akan mendorong peningkatan harga saham.

\section{Pengaruh Return on Equity Terhadap Harga Saham}

Profitabilitas merupakan ukuran seberapa besar keuntungan yang dapat diperoleh dari modal saham, tingkat penjualan dan kekayaan (assets) yang dimiliki perusahaan. Profitabilitas yang tinggi merupakan suatu keberhasilan perusahaan dalam memperoleh laba serta menunjukkan kinerja perusahaan yang baik. Investor yang rasional tentu saja akan memilih investasi pada perusahaan yang memiliki profitabilitas tinggi, sehingga akan mendorong peningkatan harga saham yang diterima investor Bisara dan Amanah (2015). Pengaruh positif profitabilitas terhadap harga saham dibuktikan dalam penelitian oleh Agustina \& Noviri (2013).

\section{Hipotesis}

Berdasarkan kajian pustaka di atas maka dirumuskan hipotesisi yakni: nilai tukar, tingkat suku bunga SBI, inflasi, produk domestik bruto dan profitabilitas berpengaruh signifikan terhadap harga saham pada perusahaan manufaktur yang terdaftar di Bursa Efek Indonesia dengan profitabilitas sebagai variabel intervining.

\section{Jenis Penelitian.}

\section{METODE PENELITIAN}

Penelitian ini bertujuan untuk mengidentifikasi pengaruh ekonomi makro yaitu nilai tukar, tingkat suku bunga, inflasi dan Produk Domestik Bruto terhadap harga saham dengan profitabilitas sebagai variabel intervening pada perusahaan manufaktur yang terdaftar di Bursa Efek Indonesia Periode 2014-2017, maka dengan demikian jenis penelitian ini adalah kausal.

\section{Populasi dan Sampel.}

Populasi dalam penelitian ini adalah seluruh perusahaan manufaktur yang terdaftar di Bursa Efek Indonesia sampai Tahun 2018 yakni sebanyak 159 perusahaan. Sampel dalam penelitian ini sebanyak 61 perusahaan yang diperoleh dengan menggunakan rumus Slovin.

\section{Operasionalisasi Variabel.}

Penelitian ini menggunakan variabel terikat, variabel bebas dan variabel intervening yakni:

a. Variabel Terikat. Variabel terikat (HS) adalah harga saham perusahaan manufaktur yang terdaftar di Bursa Efek Indonesia

b. Variabel Bebas. Variabel bebas (X) dalam penelitian ini meliputi.

1) Nilai Tukar (NT). Nilai tukar \$US/Rupiah yakni nilai dari mata uang Dollar AS yang ditranslasikan dengan mata uang Rupiah yang dihitung menggunakan rumus dibawah ini: 


$$
\text { Nilai Tukar }=\frac{\text { Kurs Beli }+ \text { Kurs Jual }}{2}
$$

2) Suku Bunga (SB). Tingkat suku bunga yang digunakan dalam penelitian ini adalah tingkat suku bunga SBI yang dapat diukur dengan menggunakan rumus:

$$
\mathrm{BI}=\frac{\text { BI Rate } \text { Tahun }-t}{12}
$$

3) Inflasi (INF). Inflasi adalah kecenderungan terjadinya peningkatan harga produk secara keseluruhan yang diukur dengan rumus berikut ini:.

$$
\mathrm{IR}_{\mathrm{a}}=\frac{\mathrm{IHK}_{\mathrm{n}}}{\operatorname{IHK}_{(n-1)}} \times 100 \%
$$

4) Produk Domestik Bruto. PDB adalah nilai uang yang dihitung berdasarkan harga pasar dari keseluruhan barang-barang dan juga jasa yang telah diproduksi oleh sebuah perekonomian dalam suatu periode waktu satu tahun.

c. Variabel Intervening. (ROE) adalah Return On Equity dapat dihitung menggunakan rumus:

$$
\mathrm{ROE}=\frac{\text { Earning After Tax }}{\text { Equitas }}
$$

\section{Metode Pengumpulan Data.}

Jenis data yang digunakan dalam penelitian ini adalah data sekunder berupa laporan pertahun yang diperoleh dari situs resmi Bursa Efek Indonesia yaitu www.idx.co.id, situs resmi Badan Pusat Statistik yaitu www.bps.go.id, dan juga situs resmi Bank Indonesia yaitu www.bi.go.id selama Periode 2014-2017 dengan metode pengumpulan teknik dokumentasi.

\section{Teknik Analisis Data.}

Teknik analisis data yang digunakan dalam penelitian ini adalah analisis regresi linier berganda dengan persamaan sebagai berikut:

1. Secara Langsung. $\mathrm{ROE}=\alpha+\beta_{1} \mathrm{NT}+\beta_{2} \mathrm{SBI}+\beta_{3} \mathrm{INF}+\beta_{4} \mathrm{PDB}+\varepsilon_{1: .}$

2. Secara Tidak Langsung. HS $=\alpha+\beta_{5} \mathrm{NT}+\beta_{6} \mathrm{SBI}+\beta_{7} \mathrm{INF}+\beta_{8} \mathrm{PDB}+\beta_{9} \mathbf{R O A}+\varepsilon_{2}$. (6)

$\beta_{1}-\beta_{9}:$ Koefisien Standardized

$\varepsilon_{1} \& \varepsilon_{2}:$ Error of term atau Variabel Pengganggu

\section{Pengujian Asumsi Klasik.}

Model regresi linier dapat disebut sebagai model yang baik jika model regresi linear tersebut dikatakan BLUE (Best Linear Unbiased Estimation). Untuk itu maka perlu dilakukan pengujian untuk mengetahui model regresi yang dihasilkan memenuhi persyaratan asumsi klasik diantaranya: (1) Uji Normalitas, (2) Uji Heterokedastisitas, (3) Uji Multikolinearitas, (4) Uji Autokorelasi.

\section{Pengujian Hipotesis.}

Untuk menguji pengaruh variabel makroekonomi (nilai tukar, tingkat suku bunga, inflasi dan PDB secara parsial dan simultan terhadap variabel harga saham dengan profitabilitas sebagai variabel intervening dengan menggunakan uji $\mathrm{t}$ dan $\mathrm{F}$ hitung dengan ketentuan terima hipotesis jika nilai probabilitas dibawan 5 persen dan sebaliknya

\section{Analisis Statistik Deskriptif}

\section{HASIL PENELITIAN}

Hasil analisis statistik deskriptif mengenai variabel Nilai Tukar, Tingkat Suku Bunga SBI, Inflasi, Produk Domestik Bruto, Return on Asset dan Harga Saham pada perusahaan manufaktur yang terdaftar di Bursa Efek Indonesia dengan pengamatan tahun 2014-2017, disajikan pada Tabel 1. berikut

Tabel 1: Hasil Analisis Statistik Deskriptif 


\section{Volume 20 Nomor 2, September 2020}

\begin{tabular}{|l|c|r|r|r|r|}
\hline \multicolumn{1}{|c|}{ Variabel } & N & Minimum & Maximum & \multicolumn{1}{c|}{ Mean } & Std. Deviation \\
\hline Harga Saham & 244 & 1.03 & 83800.00 & 4074.06 & 9918.85 \\
\hline Nilai Tukar & 244 & 12440.00 & 13795.00 & 13304.75 & 516.94 \\
\hline Suku Bunga SBI & 244 & 4.56 & 7.53 & 6.40 & 1.23 \\
\hline Inflasi & 244 & 3.53 & 6.42 & 5.03 & 1.37 \\
\hline PDB & 244 & 4.55 & 5.10 & 4.89 & .21 \\
\hline Return on Assets & 244 & -29.07 & 319.20 & 6.64 & 21.71 \\
\hline Valid N (listwise) & 244 & & & & \\
\hline
\end{tabular}

Sumber: Hasil Pengolahan Data SPSS

Dari Tabel 1 diatas menunjukkan bahwa harga saham perusahaan manufaktur memiliki nilai minimum sebesar 1,03, nilai maksimum sebesar 83.800 dan nilai rata-rata sebesar Rp 4074.06 dengan standar deviasi sebesar 9918,85. Kurs US\$ terhadap Rupiah memiliki nilai minimum sebesar 12.440, nilai maksimum sebesar 13.795 dan nilai rata-rata sebesar 13.304,75 dengan standar deviasi sebesar 516,94. Tingkat suku bunga minimal sebesar 4,56, tingkat suku bunga maksimal sebesar 7,53, dan nilai rata-rata sebesar 6,40 dengan standar deviasi sebesar 1,23. Tingkat inflasi minimal sebesar 3,53, tingkat inflasi maksimal sebesar 6,42 dan nilai rata-rata sebesar 5,03 dengan standar deviasi sebesar 1,37. Tingkat PDB minimal sebesar 4,55, tingkat PDB maksimal sebesar 5,10 dan nilai rata-rata pada variabel PDB sebesar 4,89 dengan standar deviasi sebesar 0,21. Tingkat ROA minimal sebesar -29,07, tingkat ROA maksimal sebesar 319,20 dan nilai rata-rata pada variabel ROA sebesar 6,64 dengan standar deviasi sebesar 21,71 .

\section{Uji Asumsi Klasik}

Hasil pengujian asumsi klasik diantaranya: adalah nilai signifikansi Kolmogorov-Smirnovuntuk terhadap kedua persamaan berturut-turut adalah 0.228 dan 0.442. Karena kedua nilai KolmogorovSmirnov lebih besar dari alpha 0.05 dengan demikian asumsi normalitas terpenuhi. Berdasarkan Scatterplots diketahui bahwa: titik-titik data menyebar di atas dan di bawah atau di sekitar angka 0, titik-titik tidak hanya mengumpul hanya di atas atau di bawah saja, Penyebaran titik-titik data tidak membentuk pola bergelombang melebar kemudian menyempit dan melebar kembali dan penyebaran titik-titik data tidak berpola. Dengan demikian dapat disimpulkan bahwa tidak terjadi masalah heterokedastisitas. Hasil nilai tolerance dari masing-masing variabel lebih besar dari 0,1 serta nilai VIF $<10$ yang artinya bahwa variabel independen dalam model regresi ini tidak terjadi multiokolinearitas untuk kedua model. Hasil Uji Autokorelasi menunjukkan nilai statistik Durbin-Watson ( $D_{\text {hitung }}$ ) untuk kedua model berturut-turut sebesar 1.529 dan 1.207. Oleh karena itu, nilai $\mathrm{DW}_{\text {hitung }}$ dalam rentang nilai -2 dan lebih kecil dari $+2(-2<1.529<+2)$. Oleh karena itu dapat disimpulkan bahwa tidak terjadi autokorelasi baik positif maupun negatif.

\section{Uji Hipotesis}

Model Pertama yaitu Pengaruh Variabel Nilai Tukar, Suku Bunga SBI, Inflasi, dan PDB Terhadap Return on Assets

Hasil pengujian secara statistik pengaruh variabel nilai tukar, suku bunga SBI, inflasi, dan PDB terhadap Return on Assets disajikan pada tabel 2 dan 3 berikut:

Tabel 2: Coefficient (1).

\begin{tabular}{|c|c|c|c|c|}
\hline Variabel & Koefisien $\beta$ & $\mathrm{t}_{\text {hitung }}$ & $\mathrm{t}_{\text {tabel }}(5 \%)$ & Sig \\
\hline (constant) & -0.685 & -2.146 & 1.651308 & 0.033 \\
\hline Nilai Tukar $\rightarrow$ ROA $\rightarrow \boldsymbol{\beta}_{X \mathbf{1} Z}$ & -0.118 & -2.312 & 1.651308 & 0.022 \\
\hline Suku Bunga SBI $\rightarrow$ ROA $\rightarrow \boldsymbol{\beta}_{X \mathbf{2} Z}$ & 0.595 & 10.669 & 1.651308 & 0.000 \\
\hline Inflasi $\rightarrow$ ROA $\rightarrow \boldsymbol{\beta}_{X \mathbf{3} Z}$ & 0.130 & 2.562 & 1.651308 & 0.011 \\
\hline $\mathrm{PDB} \rightarrow \mathrm{ROA} \rightarrow \boldsymbol{\beta}_{\boldsymbol{X} \mathbf{Z} Z}$ & 0.155 & 2.773 & 1.651308 & 0.006 \\
\hline
\end{tabular}

Sumber:Data diolah

Tabel 3: Anova

Pengaruh Variabel Makro Ekonomi Terhadap Harga Saham dengan Profitabilitas Sebagai 
Volume 20 Nomor 2, September 2020

\begin{tabular}{|l|l|r|r|r|r|l|}
\hline \multicolumn{2}{|l|}{ Model } & Sum of Squares & Df & Mean Square & F & Sig. \\
\hline \multirow{4}{*}{1} & Regression & 210.169 & 4 & 52.542 & 47.281 & $.000^{\mathrm{a}}$ \\
\cline { 2 - 7 } & Residual & 221.142 & 199 & 1.111 & & \\
\cline { 2 - 8 } & Total & 431.312 & 203 & & & \\
\hline
\end{tabular}

a. Predictors: (Constant), PDB, Inflasi, Nilai Tukar, Suku Bunga SBI

b. Dependent Variable: Return on Assets

Dari tabel 2 di atas menunjukkan bahwa nilai tukar berpengaruh negatif dan signifikan terhadap Return on Assets pada $\alpha=5$ persen, sedangkan suku bunga SBI, inflasi dan PDB berpengaruh positif dan signifikan terhadap Return on Assets pada $\alpha=5$ persen dan dari tabel 3 di atas dapat disimpulkan bahwa nilai tukar, suku bunga SBI, inflasi dan PDB secara simultan berpengaruh signifikan terhadap profitabilitas ROA.

Model Kedua Pengaruh Langsung Variabel Nilai Tukar, Suku Bunga SBI, inflasi, PDB, dan Return on Assets Terhadap Harga Saham

Hasil pengujian secara statistik pengaruh variabel nilai tukar, suku bunga SBI, inflasi, dan PDB terhadap Return on Assets disajikan pada tabel 4 dan 5 berikut

Tabel 4. Coefficient (2)

\begin{tabular}{|l|r|c|c|c|}
\hline \multicolumn{1}{|c|}{ Variabel } & Koefisien $\beta$ & $t_{\text {hitung }}$ & $t_{\text {tabel }}(5 \%)$ & Sig \\
\hline (constant) & 6.342 & 13.984 & 1.651308 & 0.000 \\
\hline Nilai Tukar $\rightarrow$ Harga Saham $\rightarrow \boldsymbol{\beta}_{\boldsymbol{X 1} \boldsymbol{Y}}$ & -0.239 & -4.051 & 1.651308 & 0.000 \\
\hline Suku Bunga SBI $\rightarrow$ Harga Saham $\rightarrow \boldsymbol{\beta}_{\boldsymbol{X 2} \boldsymbol{Y}}$ & -0.161 & -2.012 & 1.651308 & 0.046 \\
\hline Inflasi $\rightarrow$ Harga Saham $\rightarrow \boldsymbol{\beta}_{\boldsymbol{X 3} \boldsymbol{Y}}$ & 0.181 & 3.062 & 1.651308 & 0.003 \\
\hline $\mathrm{PDB} \rightarrow$ Harga Saham $\rightarrow \boldsymbol{\beta}_{\boldsymbol{X} \mathbf{Y}}$ & 0.161 & 2.470 & 1.651308 & 0.014 \\
\hline $\mathrm{ROA} \rightarrow$ Harga Saham $\rightarrow \boldsymbol{\beta}_{\boldsymbol{Z} \boldsymbol{Y}}$ & 0.456 & 5.622 & 1.651308 & 0.000 \\
\hline
\end{tabular}

Sumber:Data diolah

Tabel 5: Anova

\begin{tabular}{|l|l|r|r|r|c|c|}
\hline \multicolumn{2}{|l|}{ Model } & Sum of Squares & \multicolumn{1}{c|}{ df } & Mean Square & F & Sig. \\
\hline \multirow{3}{*}{1} & Regression & 216.022 & 5 & 43.204 & 19.693 & $.000^{\mathrm{a}}$ \\
\cline { 2 - 7 } & Residual & 434.394 & 198 & 2.194 & & \\
\cline { 2 - 7 } & Total & 650.416 & 203 & & & \\
\hline
\end{tabular}

a. Predictors: (Constant), Return on Assets, Nilai Tukar, Inflasi, PDB, Suku Bunga

SBI

b. Dependent Variable: Harga Saham

Sumber:Hasil Pengolahan Data SPSS

Dari tabel 4 di atas menunjukkan bahwa nilai tukar dan suku bunga berpengaruh negatif dan signifikan terhadap harga saham pada $\alpha=5$ persen, sedangkan inflasi, PDB dan ROA secara langsung berpengaruh positif dan signifikan terhadap harga saham pada $\alpha=5$ persen, dan berdasarkan Tabel 5 diatas dapat dsimpulkan bahwa nilai tukar, suku bunga SBI, inflasi, PDB dan ROA berpengaruh secara simultan terhadap harga saham pada $\alpha=5$ persen

Hasil Pemeriksaan Validitas Model

Dari keseluruhan hasil koefisien $\beta$ untuk pengaruh langsung pengaruh tidak langsung dan pengaruh total menunjukkan bahwa variabel ROA sempurna berperan memediasi hubungan antara variabel suku bunga SBI terhadap harga saham. Hal ini dapat dibuktikan dengan nilai koefisien tidak langsung variabel suku bunga SBI lebih besar daripada pengaruh langsungnya. Sementara itu ROA tidak sempurna berperan memediasi hubungan antara variabel nilai tukar, inflasi dan PDB. Hal ini ditunjukkan dari nilai koefisien pengaruh langsung yang lebih besar daripada koefisien pengaruh tidak langsung. Untuk lebih jelasnya dapat divisualisasikan pada Gambar 1 berikut: 


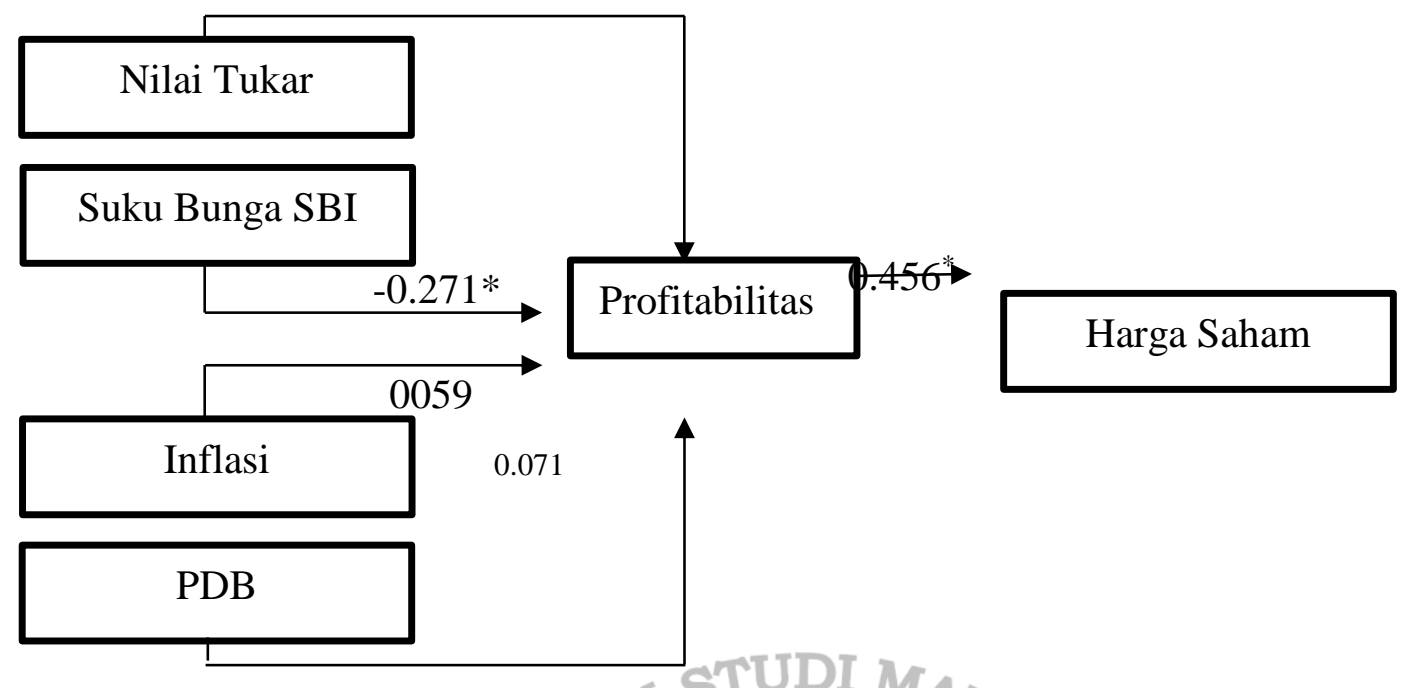

Gambar 1: Diargam Path Analysis Hubungan Tidak Langsung

\section{Keterangan: *(signifikan)}

Nilai R square sebesar 0.487 hal ini menunjukkan variasi perubahan tingkat hubungan antara nilai tukar, suku bunga SBI, inflasi dan PDB terhadap ROA sebesar $47.7 \%$ sementara sisanya $52.3 \%$ dipengaruhi oleh faktor lain dari luar penelitan yang dilakukan. Sedangkan hasil model kedua menunjukkan nilai $\mathrm{R}$ square 0.332 artinya kemampuan variabel eksogen dalam menjelaskan variasi perubahan tingkat hubungan antara nilai tukar, suku bunga SBI, inflasi, PDB, dan ROA terhadap harga saham sebesar $31.5 \%$ sementara sisanya $68.5 \%$ dipengaruhi oleh faktor lain dari luar penelitian yang dilakukan.

\section{PEMBAHASAN}

\section{Pengaruh Parsial Nilai Tukar, Suku Bunga SBI, Inflasi dan PDB Terhadap Return on Assets}

Nilai tukar satu mata uang tersebut memungkinkan mengalami terapresiasi atau terdepresiasi. Pengaruh negative nilai tukar terhadap ROA mengindikasihkan bahwa ketika mata uang rupiah melemah terhadap \$US, biaya produksi yang mengandalkan bahan baku impor akan naik hal ini akan membuat perusahaan akan mengeluarkan biaya lebih banyak untuk mengimpor bahan baku yang mana hal ini akan menurunkan ROA perusahaan dan sebaliknya. Hasil penelitian ini senada dengan penelitian yang dilakukan oleh A'yun (2017) dan Hidayati (2014). Namun, hal ini bertolak belakang dengan penelitian yang dilakukan oleh Prastowo, Malavia dan Wahono (2014).

Menurut Saputro (2018) bahwa BI Rate adalah suku bunga kebijakan yang mencerminkan sikap atau stance kebijakan moneter yang ditetapkan oleh Bank Indonesia dan diumumkan kepada publik. Dalam penelitian ini didapatkan bahwa suku bunga SBI berpengaruh positif dan signifikan terhadap ROA. Hal ini mengindikasikan bahwa, semakin tinggi tingkat suku bunga SBI akan membuat ROA perusahaan meningkat. Dalam hal ini suku bunga digunakan sebagai ukuran biaya modal yang harus dikeluarkan perusahaan untuk menggunakan dana dari pemilik modal yang disebut dengan pinjajman. Naiknya suku bunga akan ditanggung oleh investor, yaitu berupa kenaikan biaya bunga bagi perusahaan. Dapat disimpulkan bahwa hasil penelitian ini mendukung penelitian yang dilakukan sebelumnya oleh Swandayani et. All (2012) dan Alim (2014).

Menurut Mankiew (2007) inflasi adalah kenaikan harga-harga secara umum berlaku dalam suatu perekonomian dari satu periode ke periode lainnya, sedangkan tingkat inflasi adalah presentasi kenaikan harga-harga pada satu tahun tertentu dibanding dengan tahun sebelumnya. Kenaikan harga barang yang disebabkan inflasi tentunya akan menambah pengeluaran produksi perusahaan manufaktur. Dalam penelitian ini didapatkan bahwa inflasi berpengaruh positif dan signifikan terhadap ROA. Pengaruh positif inflasi terhadap ROA mengindikasikan bahwa semakin tinggi tingkat inflasi maka akan membuat ROA perusahaan meningkat. Pendapat ini didasarkan pada asumsi bahwa inflasi yang terjadi adalah demand and inflationyaitu inflasi yang terjadi karena adanya kelebihan permintaan atas penawaran barang yang tersedia. Pada inflasi seperti ini, perusahaan membebankan peningkatan biaya 


\section{Volume 20 Nomor 2, September 2020}

kepada konsumen dengan proporsi yang lebih besar sehingga keuntungan perusahaan meningkat. Dapat disimpulkan bahwa hasil penelitian ini mendukung penelitian yang dilakukan oleh Sahara (2013) dan Namun, hal ini berbeda dengan penelitian yang dilakukan oleh Kalengkongan(2011).

PDB adalah nilai pasar dari sejumlah barang dan jasa akhir yang diproduksi dalam sebuah negara pada suatu periode. PDB dapat mengukur total pendapatan maupun total pengeluaran perekonomian untuk barang dan jasa.Dalam penelitian ini didapatkan hasil bahwa PDB berpengaruh positif dan signifikan terhadap ROA. Hal ini mengindikasikan bahwa semakin bertumbuhnya PDB akan meningkatkan ROA perusahaan. Jika pertumbuhan ekononomi membaik, maka daya beli masyarakatpun ikut meningkat, dan hal ini merupakan kesempatan bagi perusahaan untuk meningkatkan penjualannya. Dengan meningkatnya penualan perusahaan, maka kesempatan perusahaan memperoleh keuntungan juga akan semakin meningkat. Dapat disimpulkan bahwa hasil penelitian ini mendukung penelitian terdahulu yang dilakukan oleh Riyanto dan Asakdiyah (2016) dan Sodiq (2015).

\section{Pengaruh Nilai Tukar Terhadap Harga Saham}

Hasil pengujian pada variabel nilai tukar terbukti berpengaruh negatif dan signifikan terhadap harga saham perusahaan manufaktur. Adanya penurunan dollar terhadap rupiah menunjukkan semakin membaiknya keadaan perekonomian di Indonesia. Dengan semakin membaiknya perekonomian di Indonesia membuat persepsi positif bagi investor untuk menanamkan dananya di perusahaan Indonesia, sehingga akan meningkatkan harga saham perusahaan manufaktur. Dapat disimpulkan bahwa hasil penelitian mendukung penelitian sebelumnya yang dilakukan oleh Wicaksono (2018) Namun, penelitian ini bertolak belakang dengan penelitian yang dilakukan oleh Mardiyati \& Rosalina (2013) dan Kewal (2012).

\section{Pengaruh Suku Bunga SBI Terhadap Harga Saham}

Hasil pengujian pada variabel suku bunga SBI terbukti berpengaruh negatif dan signifikan terhadap harga saham perusahaan manufaktur. Ketika BI Rate naik, maka akan diikuti dengan naiknya suku bunga lain dalam konteks ini suku bunga kredit. Naiknya suku bunga kredit akan meningkatkan biaya sehingga kondisi ini akan menurunkan kemampuan perusahaan untuk mengembangkan bisnisnya. Dapat disimpulkan bahwa hasil penelitian ini mendukung penelitian sebelumnya yang dilakukan oleh Budiantara (2012).

\section{Pengaruh Inflasi Terhadap Harga Saham}

Hasil pengujian pada variabel inflasi terbukti berpengaruh positif dan signifikan terhadap harga saham perusahaan manufaktur. Hal ini disebabkan karena melihat parah tidaknya inflasi yang terjadi, apabila inflasi ringan maka akan berdampak positif bagi perekonomian. Dengan terjadinya inflasi ringan tersebut tidak membuat para investor ragu untuk menanamkan dananya pada perusahaan manufaktur di Indonesia, dengan demikian akan mendorong peningkatan harga saham perusahaan manufaktur tersebut, Dapat disimpulkan hasil penelitian ini mendukung hasil penelitian sebelumnya yang dilakukan oleh Asih dan Akbar (2016) Namun, penelitian ini bertolak belakang dengan Thobarry (2009).

\section{Pengaruh PDB Terhadap Harga Saham}

Hasil pengujian pada variabel PDB terbukti berpengaruh positif dan signifikan terhadap harga saham perusahaan manufaktur. Menurut pendekatan produksi, Produk Domestik Bruto (PDB) adalah jumlah nilai barang dan jasa akhir yang dihasilkan oleh berbagai unit produksi diwilayah suatu negara dalam jangka waktu setahun. Meningkatnya PDB merupakan sinyal yang baik (positif) untuk investasi. Adanya peningkatan permintaan terhadap produk perusahaan akan meningkatkan profit perusahaan dan pada akhirnya dapat meningkatkan harga saham perusahaan. Dapat disimpulkan bahwa hasil penelitian ini mendukung penelitian terdahulu yang dilakukan oleh Hismendi et.all (2013) dan Prasetyanto (2016).

\section{Pengaruh Return on Assets (ROA) Terhadap Harga Saham}




\section{Volume 20 Nomor 2, September 2020}

Hasil pengujian pada variabel ROA terbukti berpengaruh positif dan signifikan terhadap harga saham perusahaan manufaktur.Profitabilitas merupakan ukuran seberapa besar keuntungan yang dapat diperoleh dari modal saham, tingkat penjualan dan kekayaan (assets) yang dimiliki perusahaan. Profitabilitas yang tinggi merupakan suatu keberhasilan perusahaan dalam memperoleh laba serta menunjukkan kinerja perusahaan yang baik. Dengan peningkatan ROA maka akanmenaarik investor untuk menanamkan dana nya ke perusahaan karena akan memberika return yang tinggi pula, dengan demikian akan meningkatkan harga saham perusahaan.

\section{Pengaruh Nilai Tukar, Suku Bunga SBI, Inflasi dan PDB Terhadap Harga Saham Melalui Profitabilitas}

Hasil analisa probabilitas sebagai variabel intervening menunjukkan bahwa suku bunga SBI dapat mempengaruhi harga saham pada perusahaan manufaktur di Bursa Efek Indonesia melalui profitabilitas yang diproyeksikan oleh Return on Assets yang dapat dibuktikan dari nilai pengaruh tidak langsung melalui ROA lebih besar daripada pengaruh langsung terhadap harga saham. Sementara itu nilai tukar, inflasi dan PDB tidak dapat mempengaruhi harga saham pada perusahaan manufaktur di Bursa Efek Indonesia melalui ROA, yang dapat dibuktikan dengan pengaruh langsung terhadap harga saham yang lebih besar dari pengaruh tidak langsung melalui ROA. Oleh sebab itu dapat disimpulkan bahwa Return on Assets tidak dapat menjadi variabel yang memediasi antara variabel suku bunga SBI terhadap harga saham.

Hasil penelitian ini mendukung hasil penelitian sebelumnya yang dilakukan oleh Winarti (2018). Secara keseluruhan dapat dikatakan bahwa analisis jalur menggambarkan pentingnya memperhatikan faktor fundamental perusahaan (internal) dalam sebuah keputusan investasi. Artinya hanya jika melihat nilai tukar, suku bunga, SBI, inflasi dan PDB maka akan ada harga yang tinggi terutama pada perusahaan yang orientasinya ekspor. Namun jika dilihat dari faktor fundamental perusahaan (internal), dapat dilihat bahwa adanya dampak yang kurang baik dari tingginya nilai tukar, suku bunga SBI, inflasi dan PDB.

\section{Kesimpulan}

\section{KESIMPULAN DAN SARAN}

Berdasarkan hasil analisis dan pembahasan maka dapat ditarik kesimpulan sebagai berikut: (a) nilai tukar berpengaruh negatif dan signifikan terhadap profitabilitas Return on Assets suku bunga SBI, inflasi dan PDRB secara parsial berpengaruh positif dan signifikan terhadap profitabilitas Return on Assets, (b) variabel nilai tukar, suku bunga SBI, inflasi dan PDB secara simultan berpengaruh dan signifikan terhadap Return on Assets, (c) nilai tukar dan suku bunga SBI secara parsial berpengaruh negatif dan signifikan terhadap harga saham, (d) inflasi, PDRB dan Return on Asset berpengaruh positif dan signifikan terhadap harga saham, dan (e) variabel nilai tukar, suku bunga SBI, inflasi, PDB dan ROA secara simultan berpengaruh dan signifikan terhadap Return on Assets.

\section{Saran}

Berdasarkan kesimpulan maka saran penelitian selanjutnya antara lain: (a) bagi calon investor diharapkan dapat lebih cermat dalam melihat faktor-faktor yang dapat mempengaruhi harga saham seperti nilai tukar, inflasi dan PDB khususnya ROA dan (b) bagi perusahaan diharap hendaknya memperhatikan kondisi ekonomi makro sebagai bahan pertimbangan dalam membuat keputusankeputusan strategis guna meningkatkan nilai perusahaan yang tercermin dari peningkatan harga saham perusahaan.

\section{DAFTAR PUSTAKA}

A’yun, Inarotul. 2017. Pengaruh Variabel Fundamental dan Makroekonomi Terhadap Harga Saham Melalui ROA. Skripsi. Malang: Program Magister Ekonomi Syariah.

Asih, Ni Wayan Sri dan Akbar, Masithah. 2016. Analisis Pengaruh Inflasi, Suku Bunga, Nilai Tukar (Kurs) dan Pertumbuhan Produk Domestik Bruto (PDB) Terhadap Indeks Harga Saham 


\section{Volume 20 Nomor 2, September 2020}

Gabungan (IHSG) Studi Kasus Pada Perusahaan Properti yang Terdaftar di Bursa Efek Indonesia. Jurnal Manajemen dan Akuntansi. Volume 17 (1).

Bramantio, Swandari dan Stiadi. 2013. Pengaruh Faktor Makroekonomi Terhadap Indeks Harga Saham di BEI Pascakrisis Ekonomi Global 2008. Jurnal Wawasan Manajemen. Vol 3 (2), pp. 119.

Budiantara, M. 2012. Pengaruh Tingkat Suku Bunga, Nilai Kurs dan Inflasi Terhadap Harga Saham Gabungan di Bursa Efek Indonesia Periode 2005-2010. JurnalSosiohumaniora . Volume 3 (3).

Hidayati, A. N. 2014. Pengaruh Inflasi, BI Rate dan Kurs Terhadap Profitabilitas Bank Syariah di Indonesia. An-Nisbah. Vol 1 (01), 73土97.

Hismendi. Hamzah, Abubakar. Musnadi, Said. 2013. Analisis Pengaruh Nilai Tukar SBI, inflasi, dan GDP Terhadap Pergerakan Indeks Harga Saham Gabungan di Bursa Efek Indonesia. Jurnal Ekonomi Pascasarjana Universitas Syiah Kuala. ISSN 2302-0172 pp. 16-28.

Kalengkongan, G. 2011. Tingkat Suku Bunga dan Inflasi Pengaruhnya Terhadap Return on Assets (ROA) pada Industri Perbankan yang Go Public di Bursa Efek Indonesia. Jurnal Emba. Vol 1 (4), $737 \pm 747$.

Kewal, Suramaya Suci. 2012. Pengaruh Inflasi, Suku Bunga, Kurs, dan Pertumbuhan PDB Terhadap Indeks Harga Gabungan. Vol 8; 1

Mankiew, N. Gregory. 2007. Makroekonomi. Erlangga: Edisi Keenam.

Mardiyati Umi dan Rosalina Ayi.2013. Analisis Pengaruh Nilai Tukar, Tingkat Suku Bunga dan Inflasi Terhadap Indeks Harga Saham (Studi Kasus Pada Perusahaan Properti yang Terdaftar di Bursa Efek Indonesia). Jurnal Riset Manajemen Sains Indonesia (JRMSI). Vol 4 (1).

Prasetyanto, Panji Kusuma. 2016. Pengaruh Produk Domestik Bruto dan Inflasi Terhadap Indeks Saham Gabungan di Bursa Efek Indonesia Tahun 2002-2009. Jurnal Riset Akuntansi dan Bisnis Airlangga Vol 1 No. 1.

Prastowo, P. R., Malavia, R. dan Wahono, B. 2014. Analisis Pengaruh Inflasi, Suku Bunga dan Nilia Tukar Terhadap Profitabilitas Perbankan. E-Jurnal Riset Manajemen. 27 \pm 41 .

Riyanto, Ibnu Seyna dan Asakdiyah, Salamatun. 2016. Analisis Pengaruh Inflasi, Jumlah Uang Beredan dan Produk Domestik Bruto Terhadap Return on Assets (ROA) Bank Syariah di Indonesia. Jurnal Fokus. Vol.6, Nomor 2.

Samsul, Mohammad. 2015. Pasar Modal \& Manajemen Portofolio. Jákarta: Erlangga.

Saputro, Seno, Hadi. 2019. Analisis Variabel Makroekonomi Terhadap Profitabilitas Pada Perusahaan

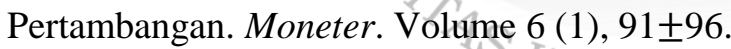

Thobarry, Achmad Ath. 2009. Analisis Pengaruh Nilai Tukar, Suku Bunga, Inflasi dan Pertumbuhan GDP Terhadap Indeks Harga Saham Properti (Kajian Empiris pada Bursa Efek Indonesia Periode Pengamatan Tahun 2000-2008). Tesis. Universitas Diponogoro. Semarang.

Jogiyanto. (2010). “Teori Portofolio dan Analisis Investasi,Edisi Ketujuh". Yogyakarta: BPFE UGM. 